\title{
Optimisme yang Tidak Menjanjikan: Kajian terhadap Transhumanisme dari Perspektif Antropologi Kristen
}

\section{An Unpromising Optimism: Examining Transhumanism from a Christian Anthropological Perspective}

\author{
Wendy, ${ }^{1 *}$ David Alinurdin ${ }^{2)}$ \\ 1) Program Studi Magister Teologi Sekolah Tinggi Teologi SAAT, Indonesia \\ 2) Sekolah Tinggi Teologi SAAT, Indonesia \\ *) Korespondensi: lim.wendy0309@gmail.com
}

\begin{abstract}
Abstrak: Transhumanisme adalah sebuah pergerakan budaya dan filsafat yang melihat manusia memiliki hak dan kebebasan morfologis untuk berevolusi mencapai kondisi pascahuman dengan memodifikasi dan meningkatkan natur serta kapasitas manusia secara radikal menggunakan teknologi terkini seperti rekayasa genetika, robotika, kecerdasan buatan dan nanoteknologi. Pascahuman yang didambakan transhumanisme adalah kondisi manusia yang tidak dapat mengalami kemerosotan, penyakit, dan bahkan kematian. Tujuan akhirnya adalah hidup lebih panjang atau bahkan abadi untuk menikmati kebahagiaan yang tidak terbatas. Dengan mencermati perkembangan agenda transhumanis, muncul keprihatinan dari para sarjana bidang interdisipliner sains, teknologi dan teologi bahwa umat manusia akan diubahkan oleh teknologi atau bahkan malah menjadi tersingkir dan punah. Artikel ini bertujuan mengkaji transhumanisme dari perspektif antropologi Kristen, yang meliputi tiga aspek, yaitu asal-usul dan natur manusia, realitas kehidupan manusia serta solusi bagi masalah manusia. Hasil kajian menunjukkan bahwa janji transhumanisme mengenai evolusi manusia dengan kebebasan morfologis dan determinasi dirinya sendiri dapat mengupayakan perkembangan menuju kondisi pascahuman adalah hal yang tidak menjanjikan untuk tercapai karena natur manusia yang telah jatuh ke dalam dosa cenderung merusak atau menggantikan yang baik menjadi jahat. Agenda dan optimisme transhumanisme untuk menyingkirkan kemerosotan, penyakit dan kematian sepenuhnya dari kehidupan manusia dengan menggunakan teknologi terkini mustahil direalisasikan karena semua realitas tersebut adalah dampak dari kejatuhan manusia ke dalam dosa yang hanya bisa diatasi dengan cara ilahi melalui karya penebusan Kristus yang mengerjakan transformasi jiwa raga secara holistik.
\end{abstract}

Kata-kata kunci: Transhumanisme, Pascahuman, Kebebasan Morfologis, Radical Life Extension, Imago Dei, Gambar Allah, Antropologi Kristen

\begin{abstract}
Transhumanism is a cultural and philosophical movement that sees humans as having the right and morphological freedom to evolve towards a posthuman state by radically modifying and enhancing human nature and capacity using the latest technologies such as genetic engineering, robotics, artificial intelligence, and nanotechnology. The posthuman that transhumanism craves is the human condition impervious to degeneration, disease, and even death. The end goal is to live longer or even immortal to enjoy unlimited happiness. By observing the development of the transhumanist agenda, there are concerns from scholars in the interdisciplinary fields of science, technology, and theology that humanity will be transformed by technology or even become marginalized and extinct. This article aims to examine transhumanism from Christian anthropology, which includes three aspects: the origin and nature of man, the reality of human life, and solutions to human problems. The results of the study show that the promise of transhumanism regarding human evolution with morphological freedom and self-determination to strive for progress towards a posthuman state is unpromising to achieve because human nature, which has fallen into sin, tends to destroy or exchange good for evil. The agenda and optimism of transhumanism to completely remove degeneration, disease, and death from human life by using the latest technology is impossible to realize because all these realities are the impact of the fall of man into sin, which can only be overcome by divine means through redemptive work of Christ which carries out the transformation of soul and body holistically.
\end{abstract}

Keywords: Transhumanism, Posthuman, Morphological Freedom, Radical Life Extension, Imago Dei, Image of God, Christian Anthropology 


\section{PENDAHULUAN}

Pandemi COVID-19 yang terjadi dalam waktu satu tahun terakhir ini telah menimbulkan perubahan sosial yang signifikan dalam berbagai aktivitas kehidupan manusia di seluruh dunia. Aktivitas-aktivitas yang biasa dilakukan secara langsung dan fisik, saat ini tidak bisa lagi dilakukan semudah sebelum pandemi. Penggunaan teknologi digital yang diperantarai oleh layar gawai telah menjadi kebiasaan baru yang lumrah dilakukan oleh semua orang di seluruh dunia untuk berinteraksi dan bersosialisasi. Di tengah mudahnya orangorang secara umum untuk menerima dan beradaptasi dengan teknologi digital, muncul kekhawatiran bahwa pandemi ini telah dieksploitasi untuk percepatan integrasi teknologi digital ke dalam kehidupan manusia, khususnya kecerdasan buatan. Naomi Klein, penulis dan aktivis sosial dari Kanada, mencermati keputusan pemerintah kota New York yang tergesa-gesa membentuk komisi istimewa terdiri dari para teknokrat di Silicon Valley untuk mempercepat terwujudnya integrasi teknologi ke dalam setiap aspek kehidupan masyarakat, sementara jenazah mereka yang meninggal karena virus masih menumpuk. ${ }^{1}$ Klein mengkhawatirkan lobi-lobi dari para petinggi di Silicon Valley tersebut hanya akan membuat pemerintah terjebak kepada prioritas yang salah dengan memilih berinvestasi lebih untuk pengembangan teknologi jarak jauh seperti

${ }^{1}$ Naomi Klein, "Screen New Deal: Under the Cover of Mass Death, Andrew Cuomo Calls in the Billionaires to Build a Hi-Tech Dystopia," The Intercept, 8 Mei 2020, https://theintercept.com/2020/05/08/andrew-cuomo-ericschmidt-coronavirus-tech-shock-doctrine, diakses 3 Februari 2021.

${ }^{2}$ Malesela John Lamola, "Covid-19, Philosophy and the Leap Towards the Posthuman," Phronimon 21 (2020): 1-18, https://upjournals.co.za/index.php/Phronimon/article/view/ 8581, diakses 3 Februari 2021.

${ }^{3}$ Ronald Cole-Turner, "Introduction: The Transhumanist Challenge," in Transhumanism and Transcendence: Christian Hope in an Age of Technological Enhancement, ed. Ronald Cole-Turner (Washington: Georgetown University Press, 2011), 1.

${ }^{4}$ Philip Ball, "After the Nobel, what next for Crispr gene-editing therapies?” The Guardian, 21 Februari 2021, telehealth, 5G, dan kendaraan tanpa pengemudi, daripada untuk kesehatan masyarakat itu sendiri. Bahkan, lebih jauh dari itu, M. John Lamola, peneliti dari Universitas Johannesburg, mengatakan bahwa pandemi ini telah menjadi katalisator bagi implementasi agenda gerakan transhumanisme terorganisir yang telah disiapkan sebelumnya, yaitu mempercepat digitalisasi kehidupan manusia dan penyatuan manusia dengan teknologi untuk menghadirkan pascahuman (posthuman). ${ }^{2}$

Fenomena di atas memperlihatkan bahwa agenda transhumanisme dalam penggunaan teknologi di masa kini dan mendatang akan terus meningkat secara eksponensial, terkhusus penggunaan teknologi dengan tujuan untuk meningkatkan kehidupan manusia dengan secara langsung memodifikasi natur manusia atau kapasitasnya. ${ }^{3}$ Upaya-upaya yang dilakukan adalah dengan mengembangkan teknologi GRIN (Genetics, Robotics, Informatics, Nanotechnology), IA (Intelligence Amplification) dan AI (Artificial Intelligence). Walaupun penggunaan teknologi tersebut sekarang tampaknya masih belum terlalu luas, tetapi riset-riset mengenai rekayasa genetika, ${ }^{4}$ kecerdasan buatan, teknologi nano, teknologi informasi, regenerasi sel, dan alat yang dapat ditanam ke dalam otak terus berjalan. ${ }^{5}$ Seiring bertambah kuat dan lazimnya teknologi seperti ini, semakin bertambah juga tantangan yang muncul secara etika. Pertanyaan yang menjadi perdebatan adalah apakah teknologi

https://www.theguardian.com/science/2021/feb/21/after-the -nobel-what-next-for-crispr-gene-editing-therapies, diakses 4 Maret 2021. Ilmuwan di China, He Jiankui dan timnya, mengklaim berhasil melakukan pengeditan gen terhadap sepasang bayi perempuan kembar, Lulu dan Nana. Lihat Jon Cohen, "Did CRISPR help-or harm-the first-ever gene-edited babies?" Science, 1 Agustus 2019, https://doi. org/10.1126/science.aay9569.

${ }^{5}$ Neuralink, salah satu perusahaan startup dari Elon Musk, menyatakan telah berhasil memasukkan peralatan elektronik nano ke dalam otak babi dan mengendalikannya dari jarak jauh, https://www.independent.co.uk/life-style/ gadgets-and-tech/news/neuralink-elon-musk-event-watchonline-live-updates-a9694996.html, diakses 4 Maret 2021. Lihat juga video dari Neuralink yang disiarkan di YouTube, https://www.youtube.com/watch? $=\mathrm{vVvmgjBL74w \& t=5s}$. 
yang langsung diterapkan pada manusia diperbolehkan atau tidak? Siapa yang berhak memutuskan boleh atau tidaknya teknologi seperti ini? Bagi transhumanisme, jawabannya adalah diperbolehkan karena keputusan tersebut terletak pada hak masing-masing manusia dalam hidupnya. ${ }^{6}$

Transhumanisme adalah sebuah pergerakan budaya dan sebuah filosofi kehidupan. Nick Bostrom, seorang filsuf Swedia di Universitas Oxford yang juga salah satu pendiri The World Transhumanist Association (WTA) yang merupakan ahli dalam bidang kecerdasan buatan dan bioetika, dalam The Transhumanist FAQ menjelaskan bahwa secara sederhana transhumanisme dapat dimengerti sebagai sebuah cara pandang mengenai masa depan yang didasarkan pada premis bahwa spesies manusia dalam bentuknya sekarang tidak merepresentasikan tahap akhir dari perkembangan manusia, melainkan barulah tahap awal dari perkembangannya. ${ }^{7}$ Jika humanisme berfokus mengembangkan manusia menggunakan pendidikan dan budaya, transhumanisme berfokus pada mengembangkan manusia melebihi dari apa yang disebut "manusia" dengan memanfaatkan perkembangan teknologi. ${ }^{8}$ Menurut Matthew Eppinette, pandangan transhumanisme ini adalah sebuah gerakan budaya yang masih kecil namun terus berkembang dan menggambarkan semangat zaman ini: "whatever can be done scientifically and technologically should be done." Transhumanisme memberikan janji bahwa di masa depan masih ada tahap berikutnya dari evolusi manusia dengan bantuan teknologi. ${ }^{10}$

\footnotetext{
${ }^{6}$ Nick Bostrom, "Transhumanist Values," Journal of Philosophical Research 30 (2005): 3, https://doi.org/10.5840/ jpr_2005_26.

${ }^{7}$ Nick Bostrom, "The Transhumanist FAQ: A General Introduction," The World Transhumanist Association (2003): 4, diakses 27 August 2020, http://www.nickbostrom. com/views/transhumanist.pdf.

${ }^{8} \mathrm{Jacob}$ Shatzer, Transhumanism and the Image of God: Today's Technology and the Future of Christian Discipleship (Downers Grove: IVP Academic, 2019), 41.

${ }^{9}$ Matthew Eppinette, "Human 2.0: Transhumanism as a Cultural Trend," in Everyday Theology: How to Read
}

Selain itu, transhumanisme juga melihat manusia dalam keterbatasan-keterbatasannya memerlukan perbaikan, transformasi, dan perubahan. Keterbatasan-keterbatasan tersebut adalah usia, kapasitas intelektual, fungsi tubuh, indra, dan emosi atau perasaan. ${ }^{11}$ Bostrom melihat manusia saat ini sangat terbatas karena belum mencapai apa yang sebenarnya dapat dicapai oleh manusia dengan "overcome many of our biological limitations." 12 Bagi Bostrom dan transhumanis yang lain, nilai manusia bukan ditentukan dari bentuk manusia saat ini melainkan ditentukan oleh tingginya otonomi individu, aspirasi dan cita-cita, pengalaman, dan jenis kehidupan yang dijalani. ${ }^{13}$ Dalam hal kematian, otonomi bahkan mendorong transhumanisme melihat setiap manusia harus memiliki hak untuk memilih kapan dan bagaimana mereka mati, atau tidak mati. ${ }^{14}$ Contohnya saja Yuval Noah Harari yang melihat kematian sebagai sebuah kesalahan teknis, sehingga kematian harusnya dapat diatasi oleh solusi teknis tanpa perlu menantikan kedatangan kedua Yesus. ${ }^{15}$

Transhumanisme juga menjunjung tinggi semangat teknisisme (technicism), yaitu suatu paham yang melihat teknologi sebagai solusi dari semua masalah manusia dan dunia. ${ }^{16} \mathrm{Ka}-$ rena itu, perubahan yang dimaksudkan dalam transhumanisme adalah perubahan yang radikal yang dilakukan dengan menerapkan teknologi pada tubuh biologis manusia secara langsung pada otak dan tubuh. ${ }^{17}$ Transhumanisme melihat teknologi sebagai sebuah alat untuk mencapai transendensi dan keabadian. Transhumanisme berusaha menggunakan teknologi untuk mengubah manusia

Cultural Texts and Interpret Trends, ed. Kevin J. Vanhoozer, Charles A. Anderson, and Michael J. Sleasman (Malang: Literatur SAAT, 2011), 192.

${ }^{10}$ Shatzer, Transhumanism and the Image of God, 16.

${ }^{11}$ Bostrom, "The Tranhusmanist FAQ," 5-7.

${ }^{12}$ Ibid., 8.

${ }^{13}$ Ibid., 4.

${ }^{14}$ Eppinette, "Human 2.0," 198.

${ }^{15}$ Yuval Noah Harari, Homo Deus: A Brief History of

Tomorrow (London: Penguin Random House, 2016), 22.

${ }^{16}$ Eppinette, "Human 2.0," 193.

${ }^{17}$ Bostrom, "The Tranhusmanist FAQ," 6. 
secara radikal. Mereka menyebut kondisi perubahan radikal itu dengan sebutan pascahuman (posthuman). ${ }^{18}$ Kondisi inilah yang menjadi tujuan akhir dari transhumanisme dan dinilai sebagai solusi bagi masalah manusia.

Mencermati perkembangan agenda transhumanisme di atas yang semakin hari semakin pesat, maka dalam beberapa tahun terakhir, muncul beberapa keprihatinan dari para pemikir di bidang studi interdisipliner filsafat, teologi dan sains terhadap hal ini. Pertama, teknologi dapat membentuk dan mengubah manusia, tanpa manusia sadari. Manusia ibarat katak di dalam panci air yang sedang dipanaskan secara perlahan-lahan di atas kompor karena tidak menaruh perhatian terhadap perubahan apa yang sedang dan sudah dilakukan teknologi kepada manusia sedikit demi sedikit. Transhumanisme menawarkan sebuah budaya masa depan. Prediksi mereka adalah suatu saat banyak orang juga akan menyukai perkembangan teknologi ini. Seiring semakin banyak orang tidak dapat membayangkan hidup tanpa gawai mereka maka transhumanis meramalkan bahwa di masa depan, kebanyakan manusia akan merasakan hal yang sama terhadap teknologi yang langsung bersentuhan dengan tubuh dan otak manusia. Jacob Shatzer menyatakan keprihatinannya bahwa penggunaan alat (tools) tertentu membentuk manusia melalui interaksinya dengan manusia. ${ }^{19}$ Bukan apakah teknologi menjadi berhala atau tidak, tetapi teknologi mengubah cara kita berpikir dan merasa, termasuk di dalamnya mengubah kemampuan manusia untuk memberikan perhatian atau fokus. Shatzer berargumen bahwa teknologi membentuk penggunanya

\footnotetext{
${ }^{18}$ Eppinette, "Human 2.0," 192.

${ }^{19}$ Shatzer, Transhumanism and the Image of God, 16.

${ }^{20}$ Ibid., 16-17. Liturgi adalah praktik ritual yang berfungsi sebagai pedagogi dari keinginan ultimat. Teknologi mempromosikan sebuah liturgi yang membentuk penggunanya untuk semakin menginginkan kebebasan dan kemampuan untuk mengontrol hal-hal yang ada di sekitar mereka, termasuk diri mereka sendiri. Liturgi ini sejalan dengan tujuan utama transhumanisme, yaitu otonomi dan
}

kepada perubahan tertentu-moral, neuron otak, relasi, daya ingat, dan lain-lain-dan menggoda penggunanya dengan visi mengenai pengembangan manusia, yaitu liturgi kontrol dan kuasa. ${ }^{20}$ Egbert Schuurman juga mendukung ide bahwa teknologi membawa sebuah budaya kontrol yang disebutnya dengan the scientific-technical ideal of control. ${ }^{21}$ Teknologi dapat membawa orang menjauh dari tujuan mandat budaya. Beberapa contoh yang diberikan Schuurman untuk mendukung pernyataannya ini adalah Kain, keturunan Lamekh, pembangunan menara Babel, dan Nebukadnezar. $^{22}$

Kedua, transhumanisme mengasumsikan bahwa natur manusia secara biologis sudah usang dan mengandung kecacatan secara inheren sehingga perlu diperbaiki, ditingkatkan atau bahkan digantikan. Hava Tirosh-Samuelson mencermati bahwa yang ditawarkan transhumanisme bukanlah tentang bagaimana manusia bisa berkembang secara biologis, sosial, dan politik tetapi sebuah visi yang merendahkan kemanusiaan kita, memanggil kita untuk meningkatkan diri kita dengan teknologi sehingga kita bisa secara sukarela menjadi punah. ${ }^{23}$ Menurutnya, transhumanisme memanggil manusia untuk melakukan bunuh diri kolektif sebagai spesies. ${ }^{24}$

Ketiga, adanya kekhawatiran bahwa pascahumanisasi pada dasarnya adalah tentang menyingkirkan manusia dari posisinya sebagai pemberi makna dengan memberikan kesempatan dan partisipasi yang sama dari spesies

hidup yang lebih baik. Shatzer menggunakan istilah liturgi kontrol untuk menjelaskan hal ini.

${ }^{21}$ Egbert Schuurman, Faith and Hope in Technology, terj. John Vriend (Toronto: Clements, 2003), 157.

${ }^{22}$ Ibid.

${ }^{23}$ Hava Tirosh-Samuelson, "In Pursuit of Perfection: The Misguided Transhumanist Vision," Theology and Science 16, no. 2 (2018): 204, https://doi.org/10.1080/147 46700.2018.1463659.

${ }^{24}$ Ibid. 
nonmanusia. ${ }^{25}$ Robot dan automata ${ }^{26}$ lain yang membawa kehidupan buatan (artificial life) dapat diterima sebagai mitra sosial yang setara dalam sistem sosial fisik-siber. ${ }^{27}$ Prinsipprinsip manusiawi dan organik diturunkan dari posisinya yang sentral dalam kehidupan. Hal ini dapat menandakan berakhirnya era manusia, yang secara harfiah bisa diartikan sebagai antroposida - pemusnahan umat manusia-ketika realitas singularitas itu mulai tersingkap. ${ }^{28}$

Dengan mencermati visi dan agenda transhumanisme di atas serta keprihatinankeprihatinan yang telah diungkapkan maka artikel ini ditulis dengan tujuan untuk mencermati lebih dalam pandangan transhumanisme mengenai (1) asal-usul dan natur manusia, (2) realitas kehidupan manusia, dan (3) solusi bagi masalah manusia, dari perspektif antropologi Kristen. Dari kajian yang dilakukan didapati bahwa janji dan agenda transhumanisme mengenai masa depan manusia yang lebih baik dengan mengandalkan teknologi adalah sebuah optimisme yang tidak menjanjikan. Sebaliknya, antropologi Kristen menawarkan perspektif yang tepat terhadap natur dan tujuan hidup manusia berdasarkan pandangan Allah Sang Pencipta itu sendiri. Kajian pertama akan melihat pandangan transhumanisme mengenai asal-usul dan natur manusia.

\section{ASAL-USUL DAN NATUR MANUSIA}

Beberapa pemikiran transhumanisme mengenai asal usul manusia yang akan dikaji adalah sebagai berikut. Pertama, transhumanisme melihat manusia berasal dan berkembang di dalam proses evolusi. ${ }^{29}$ Kondisi manusia saat

\footnotetext{
${ }^{25}$ Lamola, "Covid-19, Philosophy and the Leap Towards the Posthuman," 14

${ }^{26}$ Kata automata adalah bentuk jamak dari automaton, yaitu mesin atau mekanisme kendali yang dapat beroperasi secara otomatis dan mandiri (https://www.merriamwebster.com/dictionary/automaton, diakses 4 Maret 2021).

${ }^{27}$ Misalnya, pemerintah Jepang sedang mengupayakan Society 5.0 yang bertujuan menciptakan masyarakat fisiksiber di mana manusia dan nonmanusia seperti automata dapat hidup bersama. Lihat Matthew E. Gladden, "Who
}

ini dilihat sebagai sebuah kondisi yang berada pada satu titik dari sebuah perjalanan panjang mengenai pengembangan (development) dan perkembangan (flourishing) hidup manusia. Dalam deklarasi transhumanis juga menyatakan bahwa, "We believe that humanity's potential is still mostly unrealized. There are possible scenarios that lead to wonderful and exceedingly worthwhile enhanced human conditions." ${ }^{30}$ Potensi yang dimaksudkan oleh transhumanis dalam kalimat pertama di atas adalah sebuah potensi yang melampaui apa yang disebut dengan manusia yang dicapai dengan proses yang berkelanjutan tanpa akhir. Pemikiran dasar ini juga didorong oleh pandangan para transhumanis yang melihat dunia sebagaimana adanya tanpa keberadaan sosok ilahi yang lebih daripada manusia. Karena itu, manusia dengan usahanya sendiri dengan bantuan perkembangan teknologi dianggap perlu dan harus untuk mengusahakan perkembangan atau evolusi yang lebih lanjut menuju kondisi manusia yang lebih baik.

Kedua, transhumanisme menjunjung tinggi nilai otonomi, yaitu kemampuan dan hak bagi individu untuk merencanakan dan memilih hidup mereka masing-masing. Pemahaman ini ada dalam deklarasi transhumanisme ke- 6 dan ke-8 sebagai berikut

Policy making ought to be guided by responsible and inclusive moral vision, taking seriously both opportunities and risks, respecting autonomy and individual rights, and showing solidarity with and concern for the interests and dignity of all people around the globe. We must also consider our moral responsibilities towards generations that will exist in the future.

Will Be the Members of Society 5.0? Towards an Anthropology of Technologically Posthumanized Future Societies," Social Sciences 8, no. 5 (2019): 148, https://doi.org/10.3390/socsci8050148.

${ }^{28}$ Lamola, "Covid-19, Philosophy and the Leap Towards the Posthuman," 14-15.

${ }^{29}$ Eppinette, "Human 2.0," 195

30"Transhumanist Declaration," Humanity Plus, diakses 27 Agustus 2020, https://humanityplus.org/ philosophy/transhumanist-declaration. 
We favour allowing individuals wide personal choice over how they enable their lives. This includes use of techniques that may be developed to assist memory, concentration, and mental energy; life extension therapies; reproductive choice technologies; cryonics procedures; and many other possible human modification and enhancement technologies. ${ }^{31}$

Hak untuk mengubah diri manusia dengan bantuan mesin dan teknologi digital dianggap sebagai hak dasar masing-masing individu karena berasal dari hak untuk hidup dan hak untuk bahagia. Kebebasan untuk membentuk diri ini disebut dengan kebebasan morfologis. Bagi transhumanisme, kebebasan morfologis seorang manusia sangat terkait dengan hak determinasi diri sendiri (self-determination) secara otonom. Nilai dan kemajuan seorang individu diukur dari bagaimana seseorang memiliki otonomi untuk membentuk dirinya sendiri, kehidupannya, dan caranya berelasi dengan orang lain sesuai dengan nilai yang dipegang oleh masing-masing individu. ${ }^{32}$ Kebebasan morfologis dipandang sebagai hak yang logis, yang bersumber dari hak dasar manusia lainnya, yaitu hak untuk hidup dan hak untuk bahagia. Kedua hak ini membawa kita pada hak untuk bebas. Hak untuk bebas ini termasuk di dalamnya adalah hak untuk bertindak sesuai dengan keinginan masingmasing individu untuk bebas mengejar apa pun yang dapat membuat mereka memperoleh kesenangan. Hak ini kemudian dikembangkan oleh transhumanis sampai kepada hak masingmasing individu terhadap organ-organ tubuhnya. Mereka melihat jika tubuh tidak bebas, maka hak untuk hidup dan hak untuk bahagia tidaklah relevan. Seberapa jauh tubuh dapat

\footnotetext{
${ }^{31}$ Ibid.

${ }^{32}$ Bostrom, "The Tranhusmanist FAQ," 4; bdk. Shatzer, Transhumanism and the Image of God, 59, 102.

${ }^{33}$ Shatzer, Transhumanism and the Image of God, 5657.

${ }^{34}$ Anthony A. Hoekema, Manusia: Ciptaan Menurut Gambar Allah, trans. Irwan Tjulianto (Surabaya: Momentum, 2018), 7-14.
}

diubah? Jawabannya adalah semuanya. Perubahan ini dianggap tidak mengubah kemanusiaan seseorang selama seseorang belum mati. Hak untuk hidup, bebas, bahagia, dan tubuh membawa pada hak untuk mengubah tubuh, termasuk modifikasi otak. Hal ini yang memunculkan kemampuan serta keinginan untuk mengejar potensi tubuh melalui modifikasi. ${ }^{33}$

Bagaimanakah antropologi Kristen mencermati pandangan transhumanisme tentang asul-usul dan natur manusia? Berbeda dari transhumanisme, prasuposisi dasar yang dianut oleh kekristenan adalah keberadaan Allah sebagai Pencipta dari segala sesuatu. ${ }^{34}$ Iman Kristen menegaskan bahwa manusia bukanlah produk dari sebuah kebetulan buta dan sebuah kekuatan mekanis yang impersonal, melainkan ciptaan yang berhutang pada Allah atas eksistensinya. ${ }^{35}$ Karena itu, manusia tidak eksis secara otonom, melainkan adalah ciptaan Allah yang sepenuhnya bergantung dan bertanggung jawab kepada Allah Penciptanya (bdk. Kis. 17:25, 28). Karena manusia bukanlah hasil dari evolusi atau sebuah kebetulan, maka manusia memiliki tujuan hidup yang sudah ditentukan oleh Allah, yaitu mencerminkan dan memuliakanNya (Kej. 1:26-28; Yes. 43:7; Ef. 1:11-12; 2Kor. 3:18). ${ }^{36}$ Menjadi kudus seperti Allah kudus, menjadi baik seperti Allah baik, menjadi pribadi yang mengasihi seperti Allah adalah kasih. $^{37}$

Berbicara mengenai kebebasan morfologis, antropologi Kristen juga melihat bahwa manusia diciptakan sebagai gambar Allah (imago dei, Kej. 1:26-28) yang memiliki aspek struktural (yaitu segala karunia, kemampuan alamiah, dan daya kreativitas yang meliputi hal

\footnotetext{
${ }^{35}$ Craig M. Gay, Modern Technology and the Human Future: A Christian Appraisal (Downers Grove: IVP Academic, 2018), 136.

${ }^{36}$ John M. Frame, Systematic Theology: An Introduction to Christian Belief (Phillipsburg: P\&R Publishing, 2013), 809.

${ }^{37}$ Ibid., 1010.
} 
fisik, intelektual, spiritual, moral dan kehendak) untuk memampukan manusia menjalankan aspek fungsionalnya, yaitu hidup selaras dengan kehendak Allah (yang meliputi relasi, tindakan dan cara hidup di dalam kasih, kebenaran dan kekudusan dengan Allah, sesama dan seluruh ciptaan lainnya). ${ }^{38}$ Definisi imago dei ini mencakup pengertian bahwa manusia diciptakan sebagai wakil Allah yang diberikan mandat, otoritas, kreativitas dan kapasitas untuk mengelola bumi ini dan segala isinya bagi kemuliaan Allah dan kesejahteraan seluruh umat manusia. ${ }^{39}$ Manusia adalah homo faber yang diberikan daya kreasi untuk mengekspresikan kehendak bebas di dalam menciptakan sesuatu dari generasi ke generasi sedemikian rupa sehingga menghasilkan budaya teknologi. ${ }^{40}$ Berbeda dengan pengertian kebebasan morfologis yang dianut oleh transhumanisme, antropologi Kristen tetap membuka ruang bagi pentingnya kreativitas dan determinasi diri namun di dalam kerangka relasi antara manusia dengan Allah Penciptanya dan juga dengan seluruh tatanan penciptaan. Relasi antara manusia dengan Allah bukan dimengerti sebagai aktualisasi diri dalam arti kebebasan menentukan nasib sendiri. Aktualisasi diri dalam antropologi Kristen dimengerti sebagai kesetiaan manusia sebagai imago dei memenuhi aspek fungsionalnya dengan merespons panggilan Allah. Oleh karena itu, kebebasan morfologis tidak seharusnya dimengerti sebagai kuasa dan kebebasan untuk determinasi diri sendiri secara total, melainkan kebebasan yang

\footnotetext{
${ }^{38}$ Hoekema, Manusia, 90-93. Dalam teologi Kristen sendiri ada beberapa perbedaan pandangan di dalam menafsirkan natur imago dei, yang jika dipetakan meliputi tiga aspek, yaitu substansi, relasional dan fungsional. Pandangan substansi mengidentifikasi imago dei sebagai karakteristik atau kualitas tertentu dalam diri manusia. Pandangan relasional melihat imago dei didemonstrasikan dalam relasi dengan Allah dan sesama. Pandangan fungsional meletakkan imago dei sebagai mandat budaya untuk berkuasa dan mengelola seluruh ciptaan lainnya di dalam keselarasan dengan kehendak Allah. Penjelasan lebih rinci mengenai hal ini dapat dilihat dalam Millard J. Erickson, Christian Theology, ed. ke-3 (Grand Rapids: Baker Academic, 2013), bab 22. Dengan menggabungkan ketiga pandangan tersebut maka dapat dikatakan bahwa imago dei
}

mempersiapkan manusia untuk menjawab dan menaati panggilan Allah dengan setia. ${ }^{41}$

Ketika manusia jatuh ke dalam dosa maka manusia berdosa menggunakan aspek strukturalnya tidak dalam aspek fungsional yang sebagaimana mestinya, melainkan dengan cara-cara berdosa dan tidak taat kepada Allah. ${ }^{42}$ Karena itu, ide transhumanisme tentang keinginan manusia yang terdalam untuk berevolusi mengubah dirinya menjadi lebih baik, tidak memiliki dasar yang kuat. Isu utama di sini bukanlah tentang apakah keinginan untuk berkembang (flourishing) adalah bagian dari natur manusia atau tidak, karena memang itu adalah aspek yang inheren dalam diri manusia sebagai imago dei. Problem sebenarnya adalah bagaimana dosa telah mempengaruhi keinginan ini dan dari manakah sumber pengharapan untuk terjadinya perubahan tersebut. Menurut Arvin Gouw, berkembang (flourishing) melalui pencapaian kebebasan morfologis hanya berhasil jika sifat manusia menjadi kurang jahat dari keadaannya sekarang, atau bahwa evolusi menuntut kemajuan terus-menerus untuk menjadi lebih baik di alam semesta. ${ }^{43}$ Namun kenyataannya, asumsi transhumanisme bahwa teknologi dapat membuat natur manusia menjadi lebih baik malah terbukti sebaliknya. Gouw berpendapat bahwa di sepanjang sejarah terlihat bahwa umat manusia malah cenderung menggunakan teknologi untuk menghancurkan, seperti bom atom dan senjata biologis, karena natur manusia tidaklah netral melainkan sudah tercemar oleh dosa. ${ }^{44}$ Dapat dikatakan

bukan hanya terbatas pada aspek substansi atau struktural yang statis, namun juga didemonstrasikan dan dijalankan secara aktif dalam aspek fungsional.

${ }^{39}$ Frame, Systematic Theology, 785-786.

${ }^{40}$ Ted Peters, "Imago Dei, DNA, and the Transhuman Way," Theology and Science 16, no. 3 (2018): 355, https://doi.org/10.1080/14746700.2018.1488529.

${ }^{41}$ Shatzer, Transhumanism and the Image of God, 6465 .

${ }^{42}$ Hoekema, Manusia, 93.

${ }^{43}$ Arvin Gouw, "Optimistic Yet Disembodied: The Misguided Transhumanist Vision," Theology and Science 16 no. 2 (2018): 231, https://doi.org/10.1080/14746700.2018. 1455274.

${ }^{44}$ Gouw, "Optimistic Yet Disembodied," 230. 
bahwa asumsi transhumanis tentang kemajuan adalah naif, karena natur manusia punya kecenderungan untuk mengubah kebaikan menjadi kejahatan. ${ }^{45}$ Dengan demikian janji transhumanisme tentang evolusi manusia melalui usahanya sendiri dapat berkembang menuju kondisi yang lebih baik adalah sebuah optimisme yang tidak terlalu menjanjikan.

Dari manakah sumber pengharapan terakhir manusia untuk terjadinya perubahan diri (selftransformation) yang radikal? Antropologi Kristen melihat bahwa tujuan, arti, signifikansi, dan kepenuhan hidup manusia yang sejati dapat ditemukan hanya dalam relasinya bersama Allah melalui iman dalam Kristus. Menjadi manusia sejati berarti memiliki hubungan yang benar dengan Allah melalui Kristus. ${ }^{46}$ Harapan manusia terutama harus berdasar pada Allah, bukan pada diri sendiri atau teknologi. ${ }^{47}$ Karena itu, pengembangan (flourishing) manusia bukanlah berorientasi di sekitar diri sendiri melainkan di sekitar Allah dan sesama. Di bagian selanjutnya akan dikaji pandangan transhumanisme mengenai realitas dan kondisi kehidupan manusia.

\section{REALITAS KEHIDUPAN MANUSIA}

Bagian ini akan menganalisis pemikiran transhumanisme mengenai realitas dan kondisi kehidupan manusia. Pertama, transhumanisme melihat realitas hidup manusia-antara lain seperti penyakit, kemiskinan, keterbatasan fisik, serta kemerosotan intelektual, kapasitas indera dan emosi-sebagai penderitaan yang berada di luar kemauan atau tidak diinginkan (involuntary) sehingga harus diatasi atau dihilangkan. Bostrom mengatakan bahwa

\footnotetext{
${ }^{45}$ Ted Peters, "Theologians Testing Transhumanism," Theology and Science 13 no. 2 (2015): 131, https://doi.org/ 10.1080/14746700.2015.1023524.

${ }^{46}$ Eppinette, "Human 2.0," 200.

${ }^{47}$ Philippe Gagnon, "The Problem of Transhumanism in the Light of Philosophy and Theology," in The Blackwell Companion to Science and Christianity, ed. J.B. Stump and Alan G. Padgett (Chichester: Wiley-Blackwell, 2012), 401.

${ }^{48}$ Bostrom, "Transhumanist Value," 4.

${ }^{49}$ Ibid., 4-5.
}

rentang pikiran, perasaan, pengalaman, dan kegiatan yang dapat dialami atau dilakukan oleh organisme manusia mungkin hanya merupakan bagian kecil dari apa yang dapat dialami atau dilakukan. ${ }^{48}$ Menurutnya, tidak ada alasan untuk berpikir bahwa manusia saat ini tidak dapat melampaui batasan yang ada. Manusia hanya belum memiliki kapasitas maupun kemampuan untuk memahami bagaimana rasanya menjadi manusia yang meningkat atau berkembang secara radikal dan bagaimana pemikiran, perhatian, aspirasi, dan hubungan sosial yang mungkin dimiliki oleh pascahuman. ${ }^{49}$ Bagi Bostrom, bukanlah tidak masuk akal untuk menganggap ada sebuah ruang yang lebih besar secara radikal atau ekstrem yang memiliki nilai hidup, relasi, perasaan, dan pemikiran. ${ }^{50}$

Kedua, transhumanisme juga melihat kematian sebagai sebuah kesalahan teknis yang memiliki solusi teknis. Hal ini berujung pada keinginan mereka agar transhumanisme dapat memilih kapan dan bagaimana mereka akan mati, atau bahkan memilih untuk tidak mati. Kematian adalah satu dari tiga hal yang menjadi perhatian utama transhumanisme yang harus diatasi selain kognitif dan emosi. ${ }^{51}$ Bagi mereka, penambahan umur bukan berbicara mengenai menambahkan hanya beberapa tahun hidup saja, melainkan mengejar hidup abadi. Tujuan akhir mereka adalah manusia memiliki lebih banyak lagi waktu untuk hidup dengan penuh kesehatan, kebahagiaan, dan produktivitas. ${ }^{52}$ Alasan mereka menginginkan hidup yang lebih lama karena mereka ingin memiliki lebih banyak waktu dihabiskan dengan orang yang dikasihi, dan melihat keajaiban apa yang akan ada di masa depan. ${ }^{53}$ Setiap manusia dianggap memiliki hak untuk

${ }^{50}$ Ibid., 5 .

${ }^{51}$ Nick Bostrom, "Why I Want to Be a Posthuman When I Grow Up," dalam The Transhumanist Reader: Classical and Contemporary Essays on the Science, Technology, and Philosophy of the Human Future, ed. Max More and Natasha Vita-More (Chichester: WileyBlackwell, 2013), 31.

${ }^{52}$ Bostrom, "The Tranhusmanist FAQ," 34.

${ }^{53}$ Ibid. 
memilih kapan dan bagaimana mereka meninggal, bahkan memilih untuk tidak meninggal. Hal ini dimungkinkan karena kematian dianggap sebagai sebuah kesalahan teknis, karena itu manusia dapat mengatasinya juga secara teknis atau dengan bantuan teknologi. ${ }^{54}$

Ketiga, transhumanisme melihat bahwa manusia harus menghilangkan penderitaan atau keterbatasan yang ada. Mereka juga melihat bahwa hal-hal negatif ini harus dilampaui dengan bantuan teknologi untuk mencapai kondisi pascahuman. Hal ini ada dalam deklarasi transhumanis ke-2 yang menyatakan bahwa, "Humanity stands to be profoundly affected by science and technology in the future. We envision the possibility of broadening human potential by overcoming aging, cognitive shortcomings, involuntary suffering, and our confinement to planet Earth." ${ }^{55}$ Fokus dari pernyataan ini ada pada peningkatan dan perubahan pada manusia secara radikal menggunakan teknologi. Peningkatan yang dimaksudkan oleh transhumanisme adalah memperluas potensi manusia dengan memperpanjang umur manusia dan kemerosotan fungsi fisik lainnya yang berujung pada kematian. Pemahaman ini didasarkan pada perspektif mereka dalam melihat keterbatasan manusia, termasuk kematian.

Bagaimanakah antropologi Kristen mencermati ketiga pandangan transhumanisme di atas berkaitan dengan realitas dan kondisi kehidupan manusia? Kekristenan tidak melihat kematian, penderitaan, penyakit, dan keterbatasan fisik sebagai hal-hal negatif yang harus dihindari dengan menggunakan bantuan teknologi yang dimodifikasi kepada tubuh fisik. Sebaliknya, semua hal tersebut dilihat sebagai dampak tak terhindarkan dari pemberontakan dan kejatuhan manusia ke dalam dosa. Antropologi Kristen menjelaskan bahwa dosa telah merusak gambar dan rupa Allah dalam diri manusia (lih. Rm. 1:21, 24-25, 2832; Ef. 4:17-19. Ketika Adam dan Hawa memilih untuk melanggar perintah Allah dalam Kejadian 3, manusia sepenuhnya bertanggung jawab terhadap dosa yang mereka lakukan. Allah kemudian menjatuhkan hukuman kepada Adam, Hawa, ular, dan bumi. Mengelola tanah menjadi lebih sulit dari sebelumnya. Akibat dari hukuman ini bukan hanya mengenai agrikultural, tetapi juga rusaknya tatanan alam, seperti bencana alam dan kuman penyakit. ${ }^{56}$ Dengan demikian, penderitaan, penyakit, keterbatasan fisik, dan kekurangan lainnya yang dimiliki manusia bukanlah sesuatu yang harus dihindari, melainkan dampak yang memang harus ditanggung oleh manusia sebagai ganjaran dari dosa yang telah dilakukan oleh Adam dan Hawa.

Demikian halnya juga dengan kematian, bukanlah kesalahan teknis seperti yang dikemukakan oleh Harari, melainkan dampak dari dosa. Karena dunia ini adalah dunia yang telah jatuh dan manusia adalah ciptaan yang telah jatuh, manusia mengalami keterpisahan spiritual dari Allah dan menjadi objek penderitaan, penyakit, dan kematian. Bagian terakhir dari penghakiman Allah kepada manusia adalah manusia akan kembali menjadi debu (Kej. 3:19). Kata-kata ini mendeskripsikan kematian fisik. Fakta ini menunjukkan bahwa kematian fisik adalah salah satu dari akibat dosa. Kata Ibrani muth mengindikaskan tiga kematian, yaitu kematian fisik, rohani, dan kekal. ${ }^{57}$ Sejak kejatuhan, kematian dalam arti fisik tidak dapat dihindari oleh umat manusia. Kondisi manusia yang bisa tidak mati menjadi kondisi tidak bisa tidak mati. ${ }^{58}$ Kematian fisik juga memunculkan penderitaan bagi manusia karena disebabkan oleh penyakit, bencana, kecelakaan, atau lainnya. ${ }^{59}$ Kematian lainnya meliputi kematian rohani. Konsekuensinya juga mengakibatkan

\footnotetext{
${ }^{58}$ Ibid., 178.

${ }^{59}$ Herman Bavinck, Reformed Dogmatics: Sin and Salvation in Christ, ed. John Bolt, trans. John Vriend, vol. 3

(Grand Rapids: Baker Academic, 2006), 185.
}

\footnotetext{
${ }^{54}$ Harari, Homo Deus, 22.

55"Transhumanist Declaration."

${ }^{56}$ Hoekema, Manusia, 176.

${ }^{57}$ Ibid.
} 
manusia yang dilahirkan setelah kejatuhan berada dalam keadaan mati rohani (Ef. 2:1-2). Tidak ada manusia yang dapat mengerjakan hal yang menyenangkan Allah. ${ }^{60}$ Selain itu, pada akhirnya, manusia berdosa juga tunduk pada yang namanya kematian kekal, yaitu keterpisahan kekal dari Allah. ${ }^{61}$

Di samping akibat dosa, kematian fisik juga dapat dikatakan sebagai anugerah tersembunyi dari Allah kepada umat manusia yang telah jatuh ke dalam dosa. Dalam tafsirannya terhadap Kejadian 3:22-24, Bruce Waltke mengatakan, "In their fallenness, humans must not participate in immortality. Death is both a judgement and a release." 62 Dalam kemurahanNya, Allah mengizinkan manusia mengalami kematian fisik supaya manusia tidak terusmenerus dalam keadaan berdosa sampai kepada kekekalan. Bahkan kematian fisik menjadi sarana yang Allah pakai untuk menaklukkan dosa yang membelenggu manusia, melalui kematian dan kebangkitan Kristus (Rm. 6:3-11, 8:11; 14:9). Bagi orang percaya di dalam Kristus, kematian bukanlah keterpisahan dengan Allah dan tidak lagi menjadi hukuman atas dosa, melainkan gerbang menuju perjumpaan dengan Kristus yang dikasihi dan mengasihinya (Flp. 1:21-23), di dalam hidup yang kekal (1Kor. 15:53).

Penilaian transhumanisme terhadap realitas penderitaan dalam kehidupan manusia telah memperlihatkan konsep nilai yang tidak tepat. Pada saat para transhuman memandang keterbatasan, penyakit, dan kematian sebagai sesuatu yang buruk dan harus dihindari, maka, pada saat yang sama, hal tersebut memperlihatkan mereka menjunjung tinggi nilai manusia yang sehat, kuat, bugar, cantik, tampan, dan berumur panjang. Menanggapi hal ini, Michael Dickson memberi ilustrasi bahwa

\footnotetext{
${ }^{60}$ Frame, Systematic Theology, 860.

${ }^{61}$ Hoekema, Manusia, 177-178.

${ }^{62}$ Bruce Waltke, Genesis: A Commentary (Grand Rapids: Zondervan, 2001), 96.

${ }^{63}$ Michael Dickson, "The Imago Dei and the Imago Mundi," dalam Christian Perspectives on Transhumanism and the Church: Chips in the Brain, Immortality, and the
}

nilai kehidupan janin yang diaborsi, seorang wanita muda yang meninggal dalam kecelakaan, dan seorang lansia yang meninggal karena sebab alamiah, adalah sama dalam tiap kasus. ${ }^{63}$ Menanggapi salah satu dari ketiga kasus ini, ada orang yang mungkin sangat menyesali waktu kematiannya dan apa yang mungkin akan dialami salah satu dari ketiganya seandainya kematian itu tidak terjadi. Orang lain lagi mungkin akan menilai bahwa peristiwa kematian tersebut adalah hal yang sangat disayangkan atau bahkan buruk. Namun, semua penilaian terhadap ketiga peristiwa kematian tersebut memperlihatkan nilai jiwa yang sama, yang tidak bergantung pada panjang atau pendeknya umur seseorang. ${ }^{64}$ Dengan demikian, transhumanisme tidak tepat dalam menilai seorang manusia hanya dari aspek ekstrinsik saja seperti umur panjang, kebugaran, kekuatan dan penampilan fisik, sementara manusia memiliki aspek intrinsik, yaitu jiwa atau hati, yang tidak boleh diabaikan, dan bahkan bersifat sentral di dalam diri manusia (bdk. Ams. 4:23).

Kelemahan konsep nilai transhumanisme juga memperlihatkan kelemahan dari karakter dan cara hidup manusia yang dipandang baik oleh kaum transhuman. Bostrom mengungkapkan bahwa rekayasa genetika yang diizinkan oleh para orang tua kepada anak-anak mereka dapat mendemonstrastikan kasih dan dedikasi mereka. ${ }^{65}$ Di saat yang sama, seiring para orang tua itu berterima kasih kepada teknologi, mereka juga akan lebih mudah mencintai anak-anak mereka yang cantik/tampan, sehat, cerdas dan bahagia. Pernyataan Bostrom ini secara tidak langsung menunjukkan bahwa kebesaran kasih orang tua kepada anak atau kasih manusia kepada sesamanya baru bernilai ketika mereka bisa menggunakan teknologi untuk mengatasi segala problem hidup

World of Tomorrow, ed. Steve Donaldson and Ronald ColeTurner (Cham: Palgrave Macmillan, 2018), 100.

${ }^{64}$ Ibid.

${ }^{65}$ Nick Bostrom, "Human Genetic Enhancements: A Transhumanist Perspective," Journal of Inquiry 37, no. 4 (2003): 493-506, https://doi.org/10.1023/B:INQU.00000190 37.67783.d5. 
manusia. Pertanyaannya adalah apakah keagungan kasih bergantung pada hal eksternal? Apakah keagungan kasih baru bernilai ketika segala permasalahan manusia sudah teratasi? Ataukah justru kasih yang paling agung dan paling bernilai adalah kasih yang tetap dinyatakan dengan tulus dan penuh dedikasi meskipun keadaan masih penuh masalah dan bahkan objek yang dikasihi justru dalam kondisi yang tidak diharapkan? Itulah kemuliaan kasih Allah yang ditunjukkan di dalam Yesus Kristus ketika Ia memilih tetap untuk mengasihi manusia ciptaan-Nya yang masih dalam keadaan berdosa dan sedang memusuhi-Nya dengan cara rela mati demi menyelamatkan mereka (lih. Rm. 5:8-10). Dengan demikian, dari perspektif antropologi Kristen, penderitaan sementara di dunia bukanlah sekadar ketidaknyamanan yang harus disingkirkan, melainkan sarana yang dapat dipakai Allah untuk membentuk aspek batiniah berupa karakter ketekunan, tahan uji dan pengharapan yang pada akhirnya menghasilkan kemuliaan kekal (2Kor. 4:1617; Rm. 5:3-4).

Jadi, dari kajian di bagian ini dapat disimpulkan bahwa optimisme transhumanisme untuk menyingkirkan keterbatasan, kemerosotan, penyakit dan kematian fisik dari kehidupan manusia adalah hal yang tidak menjanjikan karena semua realitas tersebut adalah dampak yang tak terhindarkan dari kejatuhan manusia ke dalam dosa. Selain itu, nilai dan makna hidup manusia tidaklah ditentukan oleh aspek ekstrinsik semata dan kondisi eksternal di sekitarnya, melainkan juga dari aspek intrinsiknya. Selanjutnya akan dikaji upaya transhumanisme dalam mencari jalan keluar bagi permasalahan manusia.

\footnotetext{
${ }^{66}$ Eppinette, "Human 2.0," 195.

${ }^{67}$ Bostrom, "The Tranhusmanist FAQ," 5.

${ }^{68}$ Ray Kurzweil, The Singularity Is Near: When Humans Transcend Biology (London: Penguin, 2010), 125. ${ }^{69}$ Ibid., 126.
}

\section{SOLUSI BAGI MASALAH MANUSIA}

Solusi yang ditawarkan oleh transhumanisme untuk masalah manusia adalah sebagai berikut. Pertama, tujuan akhir dari agenda transhumanisme yaitu menjadi pascahuman. Para pendukung transhumanisme secara aktif mempersiapkan diri untuk menjadi pascahuman. ${ }^{66}$ Bostrom mendefinisikan kondisi pascahuman sebagai berikut: mencapai tingkat kepintaran yang sangat tinggi melebihi manusia jenius; tahan terhadap penyakit dan penuaan; memiliki gairah dan kemudaan yang tidak terbatas; dapat mengontrol keinginan, suasana hati, dan kondisi mental pribadi; dapat menghindari rasa lelah dan benci; meningkatkan kapasitas untuk merasakan cinta, seni, kenikmatan, dan ketenangan; memiliki kesadaran baru yang tidak dapat diakses oleh otak manusia saat ini. ${ }^{67}$ Era pascahuman ini akan terwujud ketika bumi telah mencapai singularitas. Munculnya singularitas ditandai oleh munculnya kecerdasan komputer yang lebih tinggi daripada kecerdasan manusia atau disebut dengan kecerdasan super. ${ }^{68}$ Masa ini diprediksi oleh Kurzweil akan muncul di tahun $2045 .^{69}$

Kedua, untuk mencapai kondisi pascahuman, kaum transhuman ingin memanipulasi tubuh fisik secara radikal. Upaya yang sering kali disebut sebagai Radical Life Extension (RLE) ini meliputi tiga cara: biologis, bionik, dan virtual. $^{70}$ Secara biologis meliputi rekayasa genetika dan bioteknologi dengan tujuan menyembuhkan penyakit genetik, peremajaan sel dan mencegah penuaan. Cara bionik didasarkan pada perkembangan nanoteknologi dan robotika, yang berusaha untuk mengganti organ tubuh tertentu yang rusak dengan pengganti buatan. Terakhir, cara virtual yang sering disebut sebagai mind uploading atau pengunggahan pikiran berupa digitalisasi informasi yang terkandung di otak

\footnotetext{
${ }^{70}$ Leandro Gaitán, "Heaven on Earth: The Mind Uploading Project as Secular Eschatology," Theology and Science 17, no. 3 (2019): 405, https://doi.org/10.1080/14746 700.2019 .1632554
} 
(seperti ingatan, pengalaman, kepribadian, dan sebagainya) untuk selanjutnya ditransfer ke mesin, sehingga membebaskan pikiran dari keterbatasan tubuh manusia. Transhumanisme melihat bahwa perubahan konsep diri atau secara mental menjadi seorang transhumanis tidaklah cukup, melainkan membutuhkan perubahan yang radikal dengan memodifikasi otak dan tubuh. ${ }^{71}$ Para kaum transhumanis meyakini bahwa pascahuman membawa kehidupan yang lebih berarti daripada kehidupan manusia saat ini. Bagi mereka, ada nilai yang lebih baik dalam dunia pascahuman yang belum dapat dimengerti oleh kapasitas pemikiran manusia pada saat ini.

Memperhatikan solusi yang ditawarkan di atas, maka dapat dikatakan visi dan agenda transhumanisme untuk mencapai pascahuman adalah antroposentrisme radikal, yaitu upaya untuk memberikan kepada manusia otoritas dan kapasitas untuk pengembangan diri, transendensi diri, dan akhirnya penebusan diri sendiri. $^{72}$ Bahkan Kurzweil menyatakan sendiri bahwa upaya untuk memperbesar neocortex otak manusia dan memasukkan nanobots adalah untuk menjadi seperti Allah (godlike). ${ }^{73}$ Agenda yang berlawanan dengan antropologi Kristen ini diungkapkan dengan baik oleh Sebastian Seung: "The Bible said that God made man in his own image. The German philosopher Ludwig Feuerbach said that man made God in his own image. The transhumanists say that humanity will make itself into God." ${ }^{44}$ Jika antropologi Kristen melihat bahwa keberadaan manusia sebagai imago dei adalah anugerah Allah yang harus direspons dengan kerendahan hati dan ketaatan kepada panggilan-Nya, maka transhumanisme melihat keberadaan manusia belum mencapai potensi maksimalnya dan harus terus diupayakan dengan berbagai cara

\footnotetext{
${ }^{71}$ Bostrom, "The Tranhusmanist FAQ," 6.

${ }^{72}$ Gaitán, "Heaven on Earth," 407.

73 Kathleen Miles, "Ray Kurzweil: In The 2030s, Nanobots In Our Brains Will Make Us 'Godlike'," Huffington Post, 10 Januari 2015, https://www.huffington post.com/entry/ray-kurzweil-nanobots-brain-godlike_us_56 0555a0e4b0af3706dbe1e2, diakses 4 Maret 2021.
}

demi mencapai keabadian. Jika antropologi Kristen percaya kepada Allah yang menciptakan manusia, maka transhumanisme percaya kepada manusia yang menciptakan allah. ${ }^{75}$

Apakah solusi pascahuman melalui RLE yang ditawarkan transhumanisme sungguh dapat mengatasi permasalahan dalam hidup manusia? Jika RLE berhasil mengatasi kematian-bukan secara teoretis atau dalam pikiran semata, melainkan secara nyata dalam kehidupan saat ini-mungkinkah transhumanisme sudah memberikan pukulan telak bagi antropologi dan soteriologi Kristen? Tidak secepat itu. Agustinus pernah berkata bahwa Allah membangkitkan kerinduan dan sukacita di dalam diri manusia untuk memuji dan memuliakan-Nya karena Allah telah menciptakan manusia bagi diri-Nya sendiri sehingga hati manusia akan terus gelisah sampai menemukan perteduhan di dalam Dia. ${ }^{76}$ Pernyataan Agustinus ini menggemakan makna dan tujuan hidup manusia yang telah Allah tetapkan (bdk. Yes. 43:7b). Jika transhumanisme mengejar keabadian seperti Allah maka antropologi Kristen menyatakan bahwa tujuan hidup manusia bukanlah mengejar keabadian tetapi persekutuan dengan Allah, atau Allah itu sendiri. Atau dengan kata lain, transhumanisme mengejar keabadian seperti Allah namun tanpa Allah, sedangkan antropologi Kristen mengejar keabadian bersama Allah. Transhumanisme telah memisahkan keabadian dari isinya yang sejati, yaitu Allah sendiri, dan sebagai akibatnya, pascahuman yang sudah mencapai keabadian tetap akan mengalami keresahan dan kehampaan seperti yang dialami manusia fana. Dengan demikian, optimisme transhumanisme untuk mencapai pascahuman yang abadi adalah hal yang tidak menjanjikan karena kondisi pascahuman yang

\footnotetext{
${ }^{74}$ Sebastian Seung, Connectome: How the Brain's Wiring Makes Us Who We Are (Boston: Houghton Mifflin Harcourt, 2012), bab 15, ebook.

${ }^{75}$ Gaitán, "Heaven on Earth," 409.

${ }^{76}$ Augustine, Confessions, 1.1.
} 
didambakan kaum transhuman tetap tidak bisa menyelesaikan masalah manusia yang paling mendasar, yaitu kematian dalam arti keterpisahan manusia dengan Allah.

Berbeda dengan visi transhumanisme, antropologi Kristen memandang bahwa kesejatian manusia sebagai ciptaan yang serupa dan segambar dengan Allah-tujuan, arti, signifikansi, kepenuhan-ditemukan hanya dalam relasinya bersama Allah melalui iman di dalam Kristus. Menjadi manusia sejati berarti memiliki hubungan yang benar dengan Allah melalui Kristus supaya kembali menjadi imago dei seperti rancangan Allah semula. Pengembangan (flourishing) manusia bukanlah berorientasi di sekitar diri sendiri melainkan di sekitar Allah dan sesama. Oleh karena itu, solusi yang ditawarkan oleh antropologi Kristen kepada manusia dengan imago dei yang telah mengalami malfungsi, yang relasi rangkap tiganya telah rusak, adalah restorasi imago dei yang hanya dimungkinkan melalui karya penebusan yang Kristus kerjakan.

Di dalam kuasa-Nya, Allah bertindak secara langsung dengan membangkitkan Kristus dari kematian supaya manusia juga dapat berbagi di dalam kebangkitan-Nya. Dengan berbagian di dalam Kristus yang adalah imago dei dan sekaligus juga homo deus (manusia-Allah) yang sejati, ${ }^{77}$ manusia dimampukan kembali untuk menggunakan aspek struktural yang dimilikinya untuk menjalankan aspek fungsional yang benar. Melalui proses regenerasi dan pengudusan manusia dapat kembali dipulihkan untuk memiliki relasi yang benar dengan Allah, sesama, dan dunia. Dalam kerangka antropologi Kristen, transformasi yang Allah kerjakan dalam upaya merestorasi gambar-Nya dalam diri manusia tidak hanya bersifat ragawi tetapi terutama pengembangan integritas dan karakter yang saleh. Surat 2 Petrus 1:3-11 mencatat bahwa janji kepada

\footnotetext{
${ }^{77}$ Menurut John Lennox hanya Yesus Kristus-lah homo deus sejati seperti yang diimpikan Yuval Noah Harari. Lihat John C. Lennox, 2084: Artificial Intelligence and the Future of Humanity (Grand Rapids: Zondervan, 2020), bab 10-12.
}

orang percaya bahwa mereka akan berbagian dalam kodrat ilahi (hidup yang kekal) diikuti dengan nasihat untuk mengembangkan iman, kebajikan, pengetahuan, penguasaan diri, ketekunan, kesalehan dan kasih, sambil tetap berjaga-jaga terhadap dosa. Di sinilah antropologi Kristen melengkapi apa yang kurang dari transhumanisme, yaitu aspek bertumbuh dalam kebajikan dengan mempraktikkan kebiasaan berbuat baik (embodied habitual practice of the good) sebagai cara untuk mengembangkan kehidupan manusia. ${ }^{78}$

Namun demikian, antropologi Kristen tidak mengabaikan tubuh jasmani sebagai hal negatif yang harus ditinggalkan, dan juga bukan hal yang tidak natural, sehingga harus dimanipulasi dan diubah untuk mendapatkan perkembangan-perkembangan tambahan guna mengatasi keterbatasan dan kemerosotan fisik yang terjadi. Tubuh fisik dan embodiment memiliki makna yang sangat penting bagi kekristenan. ${ }^{79}$ Di dalam diri Yesus Kristus yang datang ke dalam dunia, Allah mengambil rupa manusia, hidup di antara manusia, memberikan nyawa-Nya, dan kemudian bangkit dari kematian juga secara fisik (Yoh. 1:14; 1 Kor. 15:3-7). Melalui iman di dalam karya Kristus yang sempurna, relasi manusia dengan Allah dipulihkan. Oleh karena itu, selama hidup di dunia ini, mereka yang ada di dalam Kristus menantikan penggenapan keselamatan secara eskatologis di mana pada akhirnya, Allah akan memulihkan dunia ini, menghadirkan langit dan bumi yang baru, yaitu kesempurnaan dan keabadian yang akan dialami di dalam tubuh kebangkitan (Why. 21-22; 1Kor. 15:35-58). Setelah mengalami glorifikasi, manusia yang telah disempurnakan tetap adalah manusia dan tidak akan pernah menjadi Allah.

\footnotetext{
${ }^{78}$ Gouw, “Optimistic Yet Disembodied," 231.

${ }^{79}$ Gay, Modern Technology, 130-131.
} 


\section{KESIMPULAN}

Tulisan ini telah mengkaji pandangan transhumanisme dalam melihat asal usul dan natur manusia, realitas kehidupan manusia, serta solusi yang ditawarkan, dari perspektif antropologi Kristen. Hasil kajian menunjukkan bahwa pandangan transhumanisme mengenai natur, realitas, tujuan dan harapan hidup manusia adalah sebuah optimisme yang tidak menjanjikan. Pertama, janji transhumanisme tentang evolusi manusia dengan kebebasan morfologis dan determinasi dirinya sendiri dapat mengupayakan perkembangan (flourishing) menuju kondisi yang lebih baik adalah hal yang mustahil karena natur manusia yang sudah jatuh ke dalam dosa punya kecenderungan untuk mengubah kebaikan menjadi kejahatan. Sebaliknya, antropologi Kristen memahami kebebasan morfologis bukan dalam arti kuasa untuk menentukan nasib sendiri, melainkan kebebasan yang mempersiapkan manusia untuk menjawab dan menaati panggilan Allah dengan setia.

Kedua, agenda transhumanisme untuk menyingkirkan sepenuhnya keterbatasan, kemerosotan, penyakit dan kematian dari hidup manusia dengan menggunakan teknologi terkini adalah hal yang mustahil karena semua realitas tersebut adalah dampak yang tak terhindarkan dari kejatuhan manusia ke dalam dosa. Sebaliknya, antropologi Kristen memperlihatkan bahwa semua keterbatasan, kerapuhan dan bahkan kematian fisik sekalipun dapat direngkuh dan memberi makna bagi kehidupan manusia di dunia, karena di dalam Kristus, Allah sendiri telah merengkuh kerapuhan dan kematian supaya Ia dapat menaklukkan dosa dan kematian

Ketiga, antropologi transhumanisme bersifat dikotomis dalam pengertian memisahkan antara aspek eksternal-material dari manusia, yaitu tubuhnya, serta aspek internal-nonmaterial dari manusia yaitu pikirannya. Karena itu, upaya transhumanisme untuk mengatasi persoalan di dalam kehidupan manusia juga cenderung parsial dan dikotomis. Di satu sisi, transhumanisme berusaha mempertahankan aspek eksternal dari manusia (kebugaran, kesehatan dan umur panjang) namun mengabaikan aspek internal seperti integritas, kesalehan dan kebajikan karakter. Namun, di sisi lain, transhumanisme berusaha mencapai pascahuman dengan membuang tubuh jasmani yang terbatas dan mengunggah pikiran ke dalam mesin komputer atau robot supaya menjadi abadi. Dari sini terlihat bahwa solusi yang transhumanisme tawarkan bagi persoalan hidup manusia bersifat modifikasi yang parsial karena tidak melihat manusia secara utuh sebagai kesatuan psikosomatik. Sebaliknya, antropologi Kristen memperlihatkan transformasi yang Allah kerjakan bagi manusia bersifat holistik dengan cara memulihkan gambar-Nya yang rusak di dalam karya penebusan Kristus. Dengan demikian, seluruh jiwa raga dari manusia yang telah ditransformasi di dalam Kristus sekali lagi dimampukan untuk berfungsi sesuai dengan tujuan Allah menciptakannya, yaitu hidup dalam keharmonisan dengan-Nya, dengan sesama dan ciptaan lainnya. Lebih dari itu, di masa mendatang, ketika Allah menggenapi keselamatannya secara sempurna bagi seluruh ciptaan, mereka yang telah diperbarui di dalam Kristus akan menerima tubuh kebangkitan yang sesuai untuk menjalani kekekalan.

\section{REFERENSI}

Augustine. Confessions. Diterjemahkan oleh Sarah Ruden. New York: Modern Library, 2017.

Bavinck, Herman. Reformed Dogmatics: Sin and Salvation in Christ. Diedit olehh John Bolt. Diterjemahkan oleh John Vriend. Vol. 3. Grand Rapids: Baker Academic, 2006.

Bostrom, Nick. "The Transhumanist FAQ: A General Introduction." The World Transhumanist Association (2003). http://www. nickbostrom.com/views/transhumanist.pdf

. "Human Genetic Enhancements: A Transhumanist Perspective." Journal of Inquiry 37, no. 4 (2003): 493-506, 
https://doi.org/10.1023/B:INQU.00000190 37.67783.d5.

-. "Transhumanist Values." Journal of Philosophical Research 30 (2005): 3-14. https://doi.org/10.5840/jpr_2005_26.

- "Why I Want to Be a Posthuman When I Grow Up." Dalam The Transhumanist Reader: Classical and Contemporary Essays on the Science, Technology, and Philosophy of the Human Future, diedit oleh Max More and Natasha VitaMore. Chichester: Wiley-Blackwell, 2013.

Cohen, Jon. "Did CRISPR help-or harmthe first-ever gene-edited babies?" Science, 1 Agustus 2019. https://doi.org/ 10.1126/science.aay9569.

Cole-Turner, Ronald. "Introduction: The Transhumanist Challenge." In Transhumanism and Transcendence: Christian Hope in an Age of Technological Enhancement, edited by Ronald Cole-Turner. Washington: Georgetown University Press, 2011.

Dickson, Michael. "The Imago Dei and the Imago Mundi." Dalam Christian Perspectives on Transhumanism and the Church: Chips in the Brain, Immortality, and the World of Tomorrow, diedit oleh Steve Donaldson and Ronald Cole-Turner, 97115. Cham: Palgrave Macmillan, 2018.

Eppinette, Matthew. "Human 2.0: Transhumanism as a Cultural Trend." In Everyday Theology: How to Read Cultural Texts and Interpret Trends, edited by Kevin J. Vanhoozer, Charles A. Anderson, and Michael J. Sleasman. Malang: Literatur SAAT, 2011.

Erickson, Millard J. Christian Theology, ed. ke3. Grand Rapids: Baker Academic, 2013.

Frame, John M. Systematic Theology: An Introduction to Christian Belief. Phillipsburg: P\&R Publishing, 2013.

Gagnon, Philippe. "The Problem of Transhumanism in the Light of Philosophy and Theology." Dalam The Blackwell Companion to Science and Christianity, diedit oleh J. B. Stump and Alan G. Padgett, 393-405. Chichester: Wiley-Blackwell, 2012.
Gaitán, Leandro. "Heaven on Earth: The Mind Uploading Project as Secular Eschatology." Theology and Science 17, no. 3 (2019): 403-416. https://doi.org/10. 1080/14746700.2019.1632554.

Gay, Craig M. Modern Technology and the Human Future: A Christian Appraisal. Downers Grove: IVP Academic, 2018.

Gladden, Matthew E. "Who Will Be the Members of Society 5.0? Towards an Anthropology of Technologically Posthumanized Future Societies." Social Sciences 8, no. 5 (2019): 148, https://doi. org/10.3390/socsci8050148.

Gouw, Arvin. "Optimistic Yet Disembodied: The Misguided Transhumanist Vision." Theology and Science 16 no. 2 (2018): 229233. https://doi.org/10.1080/14746700.20 18.1455274.

Harari, Yuval Noah. Homo Deus: A Brief History of Tomorrow. London: Penguin Random House, 2016.

Hoekema, Anthony A. Manusia: Ciptaan Menurut Gambar Allah. Diterjemahkan oleh Irwan Tjulianto. Surabaya: Momentum, 2018.

Kurzweil, Ray. The Singularity Is Near: When Humans Transcend Biology. London: Penguin, 2010.

Lamola, Malesela John. "Covid-19, Philosophy and the Leap Towards the Posthuman.” Phronimon 21 (2020): 1-18. https://upjournals.co.za/index.php/Phroni mon/article/view/8581.

Lennox, John. 2084: Artificial Intelligence and the Future of Humanity. Grand Rapids: Zondervan, 2020.

Peters, Ted. "Theologians Testing Transhumanism." Theology and Science 13, no. 2 (2015): 130-149. https://doi.org/10.1080/ 14746700.2015.1023524.

-. "Imago Dei, DNA, and the Transhuman Way." Theology and Science 16, no. 3 (2018): 353-362. https://doi.org/ 10.1080/14746700.2018.1488529.

Schuurman, Egbert. Faith and Hope in Technology. Translated by John Vriend. Toronto: Clements, 2003. 
Seung, Sebastian. Connectome: How the Brain's Wiring Makes Us Who We Are. Boston: Houghton Mifflin Harcourt, 2012.

Shatzer, Jacob. Transhumanism and the Image of God: Today's Technology and the Future of Christian Discipleship. Downers Grove: IVP Academic, 2019.
Tirosh-Samuelson, Hava. "In Pursuit of Perfection: The Misguided Transhumanist Vision." Theology and Science 16, no. 2 (2018): 200-222, https://doi.org/10.1080/ 14746700.2018.1463659.

Waltke, Bruce. Genesis: A Commentary. Grand Rapids: Zondervan, 2001. 